\title{
Role of Religious Orientation in Predicting Marital Adjustment and Psychological Well-Being
}

\author{
Taiebeh Yeganeh $^{1^{*}}$, Hassan Shaikhmahmoodi ${ }^{2}$ \\ ${ }^{1}$ Young Researchers Club, Tonekabon Branch, Islamic Azad University, Tonekabon, Iran \\ ${ }^{2}$ Islamic Azad University, Tonekabon, Iran \\ Email: "taiebeh_yeganeh@yahoo.com
}

Received October $25^{\text {th }}, 2012$; revised December $27^{\text {th }}, 2012$; accepted January $18^{\text {th }}, 2013$

Copyright (C) 2013 Taiebeh Yeganeh, Hassan Shaikhmahmoodi. This is an open access article distributed under the Creative Commons Attribution License, which permits unrestricted use, distribution, and reproduction in any medium, provided the original work is properly cited.

\begin{abstract}
Considering indices such as dynamism and complexity of modern societies, advances in psychology science, and increasing growth of spiritual needs of human against physical ones, also with respect to increasing rate of divorce in Iran, current research was done in order to study the relationship between Religious Orientation and Marital Adjustment and Psychological Well-Being. The method of current research is descriptive-correlation. Statistic population includes all married teachers of Langroud city in 2012, which 150 individuals were selected as sample via multi level cluster sampling. Alport Religious Orientation Scale (1950), Spanir Marital Adjustment Scale (1976) and Ryff Psychological Well-Being questionnaire (1998) was used. Data analysis shows that there is meaningful relation between internal religious orientation and marital adjustment $(p=.000, \mathrm{r}=.436)$ and also between internal religious orientation and psychological well-being $(p=.000, r=.506)$. In addition, results showed that internal religious orientation is able to meaningful predictions of Marital Adjustment and Psychological Well-Being. These findings show that internal religious orientation can predict the psychological well-being and marital adjustment meaningfully. So from scientific dimension, application of religion with the meaning of inner faith is suggested in prevention and medical interferences in this area.
\end{abstract}

Keywords: Psychological Well-Being; Marital Adjustment; Religious Orientation

\section{Introduction}

According to comprehensive role of religious in improving mental health and level of psychological well-being, importance of spirituality and its growth in human being in recent decades has attracted attention of psychologists and psychiatrists (Kezdy et al., 2010; Aten \& Worthington, 2009; Aten \& Schenck, 2007). Many researches show that religious experiences have a great effect on Psychotherapy. At the same time, therapist schedule for making fundamental changes in characteristic structure of patients is related directly to these religious moods. In fact, religion as a mediator can effect on mental procedures and evaluation of daily events. Thus some researchers believe that confronting stresses and social situations are facilitated via religious believes. Furthermore, notice that attitudes of family members about religious will continuo and transfer religious values and behaviors to other generations, thus relation between religious and family is considered an interactive one (Mehoney et al., 2001).

Marital adjustment is harmony and sympathy between husband and wife in achieving common goals in life which lead to satisfaction from marriage. Marital adjustment let both sides ignore conflicts and solve them with a suitable method and achieve a positive feeling (Chen et al., 2007). Simply, marital adjustment is a method which two married person are adjusted with each other to keep their marriage (Bar-On \& Parker, 2006).

\footnotetext{
*Corresponding author.
}

Importance of adjusted marital relationships is due to its role as one of the main factors in stability and strength of this relationship (Gaal, 2005). Unclear and ambiguous condition of couples (Alois \& Bruno, 2009), problems in social relationships, tendency toward social and moral delinquency and falling of cultural values between couples are some results of marital unadjustment. Spanier (1976) define it as procedure that its results are become clear via degreasing serious problems between couples, interpersonal stresses, personal anxiety and increasing couples satisfaction from each other, stability and consultation about important marital problems (Gong, 2000).

Halford et al. (2007) notice that effective factors on marital adjustment include: personal characteristics, situational factors and life events. Mutual love, take care each other, accept and understand each other and satisfying needs. Among these, religious commitment as one of the basics of happy life is effective on marital adjustment. Many researches show these findings, as in Demaris et al. (2010) religiosity is reported to be the most important factor in marital adjustment and here results show that positive effect of religious in couples' relationship is undeniable.

So undeniable role of religious commitment in achieving marital adjustment and goal in life, having positive relation with each other and totally, psychological well-being is clear.

According to Ryff and Keyes' pattern of psychological wellbeing (1995), there are 6 main basic factors as follows: purpose in life, positive relationship with others, personal growth, self 
acceptance, autonomy, domination on environment. In this point of view, health is not the same as having no disease, in other word the emphasis is on "being well" instead of "being bad or ill" (Ryff et al., 2004). Characteristics such as adjustment, happiness, self confidence and other positive ones show healthy and psychological well-being. In this situation religious can be mentioned as a useful unifying principle and a big support for mental health. World Health Organization (WHO) uses physical, mental social and spiritual aspects in his definition for human and the latest, spiritual, is said to be effective in growth and promotion of the man (American Psychiatric Association, 2000). Thus, spirituality is an important part of peoples' life and has important effect on health and well-being. Previous researches in this filed show a stable relation between religious and psychological well-being. Result of the same researches such as Kezdi et al. (2010) reports that religious training in childhood will lead to tendency toward religion in teenagers and youths and has positive effects on their mental health. Findings of Williams (2010) express a strong relation between doing religious behavior and psychological well-being. Also, Koeing (2007) believes that mental and physical health of human has positive relation with his spiritual life and those with higher religious commitment have higher adjustment in different conditions. Hills \& Francis (2004) and Hackney \& Sanders (2003) show that those who have stronger religious/ spiritual believes, achieve higher points in mental and physical tests. Faith, doing religious customs and attending related ceremonies prevent mental problems and with its therapeutic role, improve health level and psychological well-being.

Considering indices such as dynamicity and complexity of modern societies, advances of psychology science, increasing growth of spiritual needs of human vs material one, also number of divorces in Iran as a symbol of marital disorder (Halford et al., 2007). Iran is placed in 4th placed after US, Denmark and Egypt for the large number of divorces (Gholami \& Beshlideh, 2012). Current research aims to study the relation between religious orientation and marital adjustment and psychological well-being in order to determine the role of religious commitment and use it as a complement beside other psychological theories.

\section{Method}

\section{The Sample and Sampling}

The method of current research is descriptive correlation. Statistical population includes all married teachers of Langrud City in 2012 year, which 150 of them selected as sample. First of all, the population was divided in to 5 geographical regions: North, South, Center, East and West via multi level cluster sampling $(1 \times 5=5)$. Then from each region, 3 schools were selected randomly $(1 \times 5 \times 3=15)$. And finally, all teachers were gathered $(1 \times 5 \times 3 \times 10=150)$.

\section{Research Tools}

Allport Religious Orientation Scale: Allport and Ross in 1950 introduced this scale for evaluation of religious inward and outward orientation. Based on Allport theory, an inwardoriented religious is a comprehensive one with a organized principles, in other word it is a motivated comprehensive commitment which is a goal not a mean for that. On the other hand, outward-oriented religious is something for satisfying person needs such as position and security. This test with 21 question measures the inward- and outward-religious orientation. Primary researches by Allport and Ross show that the Correlation between inward- and outward-orientation is .21. In Iran, Internal Consistency for the test is reported as .71 by Jan Bozorgi (1999) and retest reliability as .74.

Spanier Marital Adjustment Scale (D.A.S): Marital adjustment was measured by Spanier Scale which consist of 23 multi choice questions (always agree, almost always agree, sometimes disagree, often disagree, almost always disagree, always disagree). Spanier calculated the reliability of the questionnaire by Cronbach's Alpha about .96 and the validity tested by Locke-Wallace Marital Adjustment Scale. The correlation coefficient of these two scales for married and divorced couples were .86 and .88 , respectively. In other research by Spanier $\&$ Tampson, Cronbach's Alpha was reported as .91. In Iran, Cronbach's Alpha is .92 and Validity is .94 (Quoted by YarMohammadyan, 2011).

Carol Ryff Psychological Well-Being Questionnaire: It concludes 82 questions and measures 6 separate aspects of psychological well-being. Each question has 6 choices and reported Cronbach's Alpha is .83 up to .92 .

Ryff (1989) study the reliability of the test by calculation of correlation coefficient of positive psychological performance (convergence validity) and negative psychological performance (divergence validity). Results show that there is positive meaningful correlation between 6 factors of this questionnaire and those who study the positive psychological performance ( $p$ $<.001$ ) and correlation domain is .25 up to .73 which confirmed the validity. At the same time, there is negative meaningful correlation between 6 factors of this questionnaire and those who study the negative psychological performance with the range of -.03 to -.060 . He also prove that these 6 factors are independent but with internal correlation $(p<.001)$ and range of .32 up to .76 and measure the psychological wellbeing (Quoted by Maddahi, 2011).

\section{Result Analysis}

The data obtained in the research were analyzed by using appropriate statistical techniques, then explained and interpreted by forming charts. Frequency calculations were made, "Pearson r Coefficient" and stepwise Multiple Regression was calculated. When the statistical data of the study were evaluated, the significance coefficient was taken as $p<.01$.

\section{Results}

Data analyze was done by Frequency, Mean, Standard deviation, Pierson Correlation Coefficient and Stepwise Multiple Regression. There were 150 participants and the age average and Std was $(40.32 \pm 7.28)$, respectively.

Descriptive indexes of research variables are shown in Table 1.

According to Table 1, there is a meaningful relation between inward religious orientation and marital adjustment $(\mathrm{r}=.436, p$ $=.000)$ and inward religious orientation and psychological well-being $(\mathrm{r}=.506, p=.000)$ but there wasn't any meaningful relation between outward religious orientation and any of variables.

Stepwise Multiple Regressions was used for determining the role of "inward religious orientation" in predicting "marital 
Table 1.

Correlation matrix of research variables.

\begin{tabular}{llcccccc}
\hline $\mathbf{R}$ & Variables & Mean & SD & $\mathbf{1}$ & $\mathbf{2}$ & $\mathbf{3}$ & $\mathbf{4}$ \\
\hline 1 & Inward Religious Orientation & 35.77 & 7.82 & 1 & - & - & - \\
2 & Outward Religious Orientation & 29.38 & 5.81 & .005 & 1 & - & - \\
3 & Marital Adjustment & 106.53 & 8.85 & .062 & $.436^{* *}$ & 1 & - \\
4 & Psychological Well-Being & 302.25 & 26.49 & .008 & $.506^{* *}$ & $.305^{* *}$ & 1 \\
\hline Note: & ${ }^{* *}$ Correlation is significant at the .01 level (2-tailed).
\end{tabular}

adjustment". Tables 2-4 show the results.

According to Table 2, Correlation Coefficient of inward religious orientation and marital adjustment is .43 Also Coefficient of determination is .19 which means that .19\% of Variances of the "marital adjustment" variable can be determined by "inward religious orientation".

As is shown in Table 3, F $=34.66$ for "inward religious orientation", and according to significant level the variable can predict marital adjustment $(p=.000)$.

Based on Variance results and Stepwise Regression, calculated $\mathrm{T}$ in Table 4 between marital adjustment and inward religious orientation is meaningful and we conclude that "inward religious orientation" with $99.9 \%$ reliability can predict "marital adjustment".

The Regression equation for prediction of marital adjustment by inward religious orientation is as follows:

Marital Adjustment $=65.037+1.412$ (Inward Religious Orientation)

Stepwise Multiple Regression analyze was used for determination of "inward religious orientation" in prediction "psychological well-being". Results are shown in Tables 5-7.

According to Table 5, Correlation of inward religious orientation and marital adjustment is .506. Also Coefficient of determination is .25 which means that $.25 \%$ of Variances of the "psychological well-being" variable can be determined by "inward religious orientation".

As is shown in Table 6, $\mathrm{F}=51.02$ for "inward religious orientation", and according to significant level the variable can predict "psychological well-being" $(p=.000)$.

Based on Variance results and Stepwise Multiple Regression, calculated $\mathrm{T}$ in Table 7 between psychological well-being and inward religious orientation is meaningful and we conclude that "inward religious orientation" with $99 \%$ reliability can predict "psychological well-being". On the other hand, impact factor of inward orientation is which predict 7.13 of psychological well-being positively, i.e. the more inward orientation, the more improve in level of psychological well-being.

The Regression equation for prediction of psychological well-being by inward religious orientation is as follows:

Psychological Well-Being $=92.508+7.13$ (Inward Religious Orientation).

\section{Discussion}

Results show that there is positive correlation between inward religious orientation and marital adjustment which means that inward religious orientation can predict "marital adjustment". Research of Demaris et al. (2010), Nathaniel \& David (2006), Orathinkal \& Vansteewegen (2006), Hunler \& Gencoz (2005), Mahoney (2005), Marsh \& Dallos (2000) are in consistency with this research, i.e. all of them confirm a positive relation
Table 2.

Correlation Coefficient

\begin{tabular}{ccccc}
\hline Independent Variable & $\mathbf{R}$ & $\mathbf{R}^{2}$ & $\begin{array}{c}\text { Adjusted R } \\
\text { Square }\end{array}$ & $\begin{array}{c}\text { Std. Error of the } \\
\text { Estimate }\end{array}$ \\
\hline Inward Orientation & $.436^{\mathrm{a}}$ & .190 & .184 & 17.031 \\
\hline
\end{tabular}

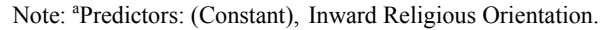

Table 3.

Results of variance prediction of Marital Adjustment by predictor var: Inward Religious Orientation.

\begin{tabular}{ccccccc}
\hline $\begin{array}{c}\text { Independent } \\
\text { Variable }\end{array}$ & $\begin{array}{c}\text { Source of } \\
\text { Changes }\end{array}$ & $\begin{array}{c}\text { Sum of } \\
\text { Squares }\end{array}$ & DF & $\begin{array}{c}\text { Mean } \\
\text { Square }\end{array}$ & F & Sig. \\
\hline \multirow{2}{\text{Inward}}{} & Regression & 10052.94 & 1 & 10052.94 & 34.66 & $.000^{\mathrm{a}}$ \\
Orientation & Residual & 42926.38 & 148 & 290.04 & & \\
& Total & 52979.33 & 149 & & & \\
\hline
\end{tabular}

Note: a Predictors: (Constant), Inward Religious Orientation; ${ }^{* *} p \leq .01 ;{ }^{\mathrm{b}}$ Dependen Variable: Marital Adjustment.

Table 4.

Variance regression of Marital Adjustment.

\begin{tabular}{cccccccc}
\hline \multirow{2}{*}{ Dependent Variable } & \multicolumn{2}{c}{$\begin{array}{c}\text { Unstandardized } \\
\text { Coefficients }\end{array}$} & $\begin{array}{c}\text { Standardized } \\
\text { Coefficients }\end{array}$ & & Sig. \\
\cline { 2 - 5 } & $\mathbf{B}$ & Std. Error & Beta & & \\
\hline $\begin{array}{c}\text { Marital } \\
\text { Adjustment }\end{array}$ & $\begin{array}{c}\text { (Constant) } \\
\text { Inward } \\
\text { Orientation }\end{array}$ & 65.037 & 7.18 & & 9.05 & .000 \\
\hline
\end{tabular}

Note: ${ }^{a}$ Dependent Variable: Marital Adjustment ${ }^{* *} p \leq .01$.

Table 5.

Correlation coefficient.

\begin{tabular}{|c|c|c|c|c|}
\hline Independent Variable & $\mathbf{R}$ & $\mathbf{R}^{2}$ & $\begin{array}{l}\text { Adjusted R } \\
\text { Square }\end{array}$ & $\begin{array}{l}\text { Std. Error of the } \\
\text { Estimate }\end{array}$ \\
\hline Inward Orientation & $.506^{\mathrm{a}}$ & .256 & .251 & 70.943 \\
\hline
\end{tabular}

Note: ${ }^{a}$ Predictors: (Constant), Inward Religious Orientation.

Table 6.

Results of Variance prediction Psychological Well-Being by predictor var: Inward Religious Orientation.

\begin{tabular}{ccccccc}
\hline Indep Var & $\begin{array}{c}\text { Source of } \\
\text { Changes }\end{array}$ & $\begin{array}{c}\text { Sum of } \\
\text { Squares }\end{array}$ & DF & $\begin{array}{c}\text { Mean } \\
\text { Square }\end{array}$ & F & Sig. \\
\hline \multirow{2}{*}{$\begin{array}{c}\text { inward } \\
\text { orientation }\end{array}$} & Regression & 256818.61 & 1 & 256818.61 & 51.02 & $.000^{\text {a }}$ \\
& Residual & 744879.26 & 148 & 5032.968 & & \\
& Total & 1001697.87 & 149 & & &
\end{tabular}

Note: ${ }^{\mathrm{a} P r e d i c t o r s: ~(C o n s t a n t), ~ I n w a r d ~ R e l i g i o u s ~ O r i e n t a t i o n ; ~}{ }^{* *} p \leq .01$; ${ }^{\mathrm{b}}$ Dependent Variable: Psychological Well-Being.

Table 7.

Variance Regression of Psychological Well-Being.

\begin{tabular}{|c|c|c|c|c|c|c|}
\hline \multirow{2}{*}{\multicolumn{2}{|c|}{ Dependent Variable }} & \multicolumn{2}{|c|}{$\begin{array}{c}\text { Unstandardized } \\
\text { Coefficients }\end{array}$} & \multirow{2}{*}{$\frac{\begin{array}{c}\text { Standardized } \\
\text { Coefficients }\end{array}}{\text { Beta }}$} & \multirow{2}{*}{$\mathbf{t}$} & \multirow{2}{*}{ Sig. } \\
\hline & & B & Std. Error & & & \\
\hline \multirow{2}{*}{$\begin{array}{c}\text { Psychological } \\
\text { Well-Being }\end{array}$} & (Constant) & 92.50 & 9.27 & & 3.09 & .002 \\
\hline & $\begin{array}{c}\text { Inward } \\
\text { Orientation }\end{array}$ & 7.13 & .999 & .506 & 7.14 & .000 \\
\hline
\end{tabular}

Note: ${ }^{\mathrm{a} D e p e n d e n t ~ V a r i a b l e: ~ P s y c h o l o g i c a l ~ W e l l-B e i n g ; ~}{ }^{* *} p \leq .01$. 
between religious commitment and marital adjustment.

Allport \& Ross (1967) believes that inward religious orientation is comprehensive with organized principles. People with inward religious orientation believe their religious training honestly and their behaviour comes from their thought and esoteric science. On the reverse, outward religious orientation is a tool for satisfying needs such as position and security. In other word in outward religious orientation, religious is in concern about unhealthy needs and aspect of human so the more outward religious orientation increase, the more marital adjustment growth. As religious give directions for life and believes, can effect on marital life positively (Hunler \& Gencoz, 2005). In marital life these directions include principles about sexual relationships, sex roles, self-sacrifice and solving conflicts (Mahoney et al., 2003).

Another aspect is effectiveness of religious on couple thinking, i.e. people with higher religious commitment, probably maybe have more spiritual life (Mahoony, 2005). While a conflict appears, religious can appear in form of common values and concepts and solve the couples' problems (Mahoney et al., 1999).

From inter-personal point of view, religious customs enable person to control his anger physiologically and emotionally, also help him accept his responsibility while conflict appears. Religious provide situations that the person pay more attention to God and act as a support for both couples to avoid conflicts. Thus relationship with God is somehow an interactive role in marital adjustment.

Another finding of current research is the positive meaningful correlation between inward religious orientation and psychological well-being which means that inward religious orientation can predict "psychological well-being". Research of Newton \& Mcintosh (2010), Williams (2010), Kezdy et al. (2010), Rodriguez \& Henderson (2010), McCullough \& Willoughby (2009), MacGregor (2008), Sorajjakol et al. (2008), Marks (2008) are in consistency with this research, i.e. all of them confirm a positive relation between religious commitment and psychological well-being.

Allport believes that it is just inward religious orientation that improves mental health. Religious provide a suitable condition for answering basic questions of human such as identity and choosing life style in order to get perfection so contribute to adjustment and psychological well-being. In inward religious orientation person gain the pleasure of connecting to the source of perfection and promotion and motivated for promotion. This motivation encourages them for living better (Allport, 1950, 1963).

Religious effect on improving level of psychological wellbeing can be expressed as providing a supportive space and "social unity source". In fact religious increases level of self confidence, adjustment and self-esteem, which are basic factors of mental health and psychological well-being, via providing social support and understanding.

Adler believes that comparison of human with the source of perfection and promotion is an important factor in psychological well-being, also accept the effect of religious in social environment and express that it is more advanced than sciences as he thinks that religious motivated people more actively. According to his point of view, religious and knowledge are the same for peoples only when knowledge can create the same enthusiasm as religious and provide the well-being of whole components of the society (Nelson \& Jones, 1957; Nelson,
1990; Nielsen, 2001).

Frankel define religious as a "search for final meaning" and believes that human nature consist of three components: spirituality, freedom and responsibility and achieving to perfection is possible only through spirituality. He thinks that main role in promotion of person and society belongs to coordination between physical, mental and religious aspect (Frankel, 1975).

Religious behaviors and beliefs with positive effect make the life meaningful. Internal relaxation mechanism via religious happens through actions such as trust in God and worship which create hope and motivate person for positive attitude. Religious functions in facing with complex situations of life will be effective through feeling of belonging to an unlimited source of power, hope to God help, benefit from social support and having goal in live (Yang \& Mao, 2007). Thus religious with important functions in peoples' life such as relaxation, giving hope, create happiness, giving meaning to life and satisfaction is useful for improving psychological well-being.

Another finding of current research is the positive meaningful correlation between marital adjustment and psychological well-being which is in consistency with researches of Vanderbleek et al. (2011), Yalcin BM, Karahan (2007), Stutzer et al. (2006), Wilson \& Oswald (2005), DePaulo \& Bella (2004), Diener et al. (2002).

Vanderbleek et al. (2011) show that those couples which spent more times with each other and have common entertainment will have more verbal and emotional communication, therefore it affects their physical and psychological health. Yalcin \& Karahan (2007) believe that training components of psychological well-being such as sympathy, responsibility and self-analysis increases marital adjustment.

Adjustment between husband and wife let them avoid conflicts and solve them in a proper way with common positive feelings and improve their level of psychological well-being (Chen et al., 2007). Emotional and psychological needs of person such as biological ones are created in family and satisfied or suppressed by family members' reactions. In an adjusted marital relationship, satisfying mental and sexual needs is a basic factor in providing the most suitable condition for promotion and perfection of peoples' well-being.

According to the results of this research, commitment to religious can create and promote level of marital adjustment and psychological well-being. Thus besides other common methods of prevention and treatment of psychological problems, important role of spirituality in marital adjustment and psychological well-being is become highlighted.

As religious and spiritual treatment methods have not gained their proper scientific position, and then such researches are necessary. It is suggested that in future researches, level of religiosity and other related factors to be evaluated in both wife and husband, also relation between religious orientation and marital adjustment and psychological well-being in other religious and various faith to be studied.

\section{Acknowledgements}

We appreciate all who helped us in this research.

\section{REFERENCES}

Allport, G. W. (1950). The individual and his religion: A psychological interpretation. New York: Macmillan. 
Allport, G. W. (1963). Behavioral science, religion, and mental health, Journal of Religion and Health, 2, 187-197. doi:10.1007/BF01533333

Allport, G. W., \& Ross, J. M. (1967). Personal religious orientation and prejudice. Journal of Personality and Social Psychology, 5, 432-443. doi: $10.1037 / \mathrm{h} 0021212$

Alois, S., \& Bruno, S. F. (2009). Does marriage make people happy, or do happy people get married? The Journal of Socio-Economic, 35, 326-367.

American Psychiatric Association (2000). Diagnostic and statistical manual of mental disorders (4th ed.). Washington DC: Heffner Media Group, Inc..

Aten, D. J., \& Worthington, E. L. (2009). Next steps for clinicians in religious and spiritual therapy: An endpiece. Journal of Clinical Psychology, 65, 224-229. doi:10.1002/jclp.20562

Aten, J. D., \& Schenck, J. E. (2007). Reflections on religion and health research: An interview with Dr. Harold G. Koenig. Journal of Religion and Health, 46, 183-190. doi:10.1007/s10943-006-9076-Z

Bar-On, R., \& Parker, J. D. A. (2006). Handbook of emotional intelligence. San Francisco: Jossey-Boss.

Chen, Z., Tanaka, N., Uji, M., Hiramura, H., \& Shikai, N. (2007). The role of personalities in marital adjustment of Japanese couples. Journal of Social Behavioral and personality, 35, 561-572. doi:10.2224/sbp.2007.35.4.561

Demaris, A., Mahoney A., \& Pargament K. I. (2010). Sanctification of marriage and general religiousness as buffers of the effects of marital inequity. Journal of Family Issues, 31, 1255-1278.

DePaulo, B. M. (2004). The scientific study of people who are single: An annotated bibliography. Glendale, CA: Academic Advisory Board of Spectrum Institute, Research and Policy Division of the American Association for Single People (AASP). URL (last checked 1 May 2007).

http://www.unmarriedamerica.org/Spectrum/Bibliography/contentsp age.htm

Diener, E., Gohm, C. L., Suh, M., \& Oishi, S. (2002). Similarity of the relation between marital status and subjective well being across cultures. Journal of Cross-Cultural Psychology, 31, 419-436. doi:10.1177/0022022100031004001

Frankel, V. E. (1975). Man's search for meaning. Boston: Beacon Press.

Gaal, F. (2005). The role of differentiation of self and anxiety in predicting marital adjustment following the death of an adult, marriedchild biological parent. Unpublished Doctoral Dissertation, Los Angels, CA: Seton Hall University.

Gholami, A., \& Beshlideh. K. (2012). The effect of spiritual therapy on mental health of divorced women. Journal of Family Counseling \& Psychotherapy, 1, 331-348.

Gong, M. (2000). Does status inconsistency matter for marital quality? Journal of Family, 28, 152-161.

Hackney, C. H., \& Sanders, G. S. (2003). Religiosity and mental health: A meta-analysis of recent studies. Journal for the Scientific Study of Religion, 42, 43-55. doi:10.1111/1468-5906.t01-1-00160

Halford, W. K., Lizzio, A., Wilson, K. L., \& Occhipinti, S. (2007). Does working at your marriage help? Couple relationship, selfregulation and satisfaction in the first 4 years of marriage. Journal of Family Psychology, 21, 185-194. doi:10.1037/0893-3200.21.2.185

Hills, P., \& Francis, L. J. (2004). Primary Personality trait correlates religious practice and orientation. Personality and Individual Differences, 36, 61-73. doi:10.1016/S0191-8869(03)00051-5

Hunler, O. S., \& Gencoz, T. I. (2005). The effect of religiousness on marital satisfaction: Testing the mediator role of marital problem solving between religiousness and marital satisfaction. Contemporary Family Therapy, 27, 123-136. doi:10.1007/s10591-004-1974-1

Janbozorgi, M. (1999). Effectiveness of psychological therapy with and without the Islamic religious orientation on anxious and stress in students. Journal of Psychology, 2, 343-368.

Kezdy, A., Martos, T., Boland, V., \& Horváth, K. (2010). Religious doubts and mental health in adolescence and young adulthood: The association with religious attitudes. Journal of Adolescence, 11, 1-9.

Koenig, H. G. (2007). Spirituality and depression: A look at the evidence. Southern Medical Journal, 10, 737-739.
doi:10.1097/SMJ.0b013e318073c68c

MacGregor, C. A. (2008). Religious socialization and children's prayer as cultural object: Boundary work in children's 19th century Sunday school books. Poetics, 36, 435-449. doi:10.1016/j.poetic.2008.06.012

Maddahi, M., Samadzadeh, M., \& Keykhayefarzaneh, M. M. (2011). The relationship between religious orientation and psychological well-being. Quarterly Journal of Educational Psychology, 2, 53-63.

Mahoney, A. (2005). Religion and conflict in marital and parent child relationship. Journal of Social Issues, 61, 689-706. doi:10.1111/j.1540-4560.2005.00427.x

Mahoney, A., paragment, K. I., Swank, A. B., \& Swank, N. (2003). Sanctification if family relationships. Review of Religious Research, 44, 220-236. doi:10.2307/3512384

Mahoney, A., Pargament, K. I., Jewell, T., Swank, A. B., Scott, E., Emery, E., \& Rye, M. (1999). Marriage and the spiritual realm: The role of proximal and distal religious constructs in marital functioning. Journal of Family Psychology, 13, 321-338. doi:10.1037/0893-3200.13.3.321

Mahoney, A., Pargament, K., Swank, A., \& Tarakeshvar, N. (2001). Religion in the home in the 1980s and 1990s: A meta-analytic review and conceptual analysis of religion, marriage and parenting. Journal of Family Psychology, 15, 559-596.

Marks, L. D. (2008). Prayer and marital intervention: Asking for divine help ... or professional trouble? Journal of Social and Clinical Psychology, 27, 678-685. doi:10.1521/jscp.2008.27.7.678

Marsh, R., \& Dallos, R. (2000). Religious beliefs and practices and Catholic couples' management of anger and conflict. Clinical Psychology and Psychotherapy, 7, 22-36. doi: 10.1002/(SICI) 1099-0879(200002)7:1<22::AID-CPP217>3.0.C $\underline{\mathrm{O} ; 2-\mathrm{R}}$

McCullough, M. E., \& Willoughby, B. L. B. (2009). Religion, selfregulation, self-control: Associations, explanations, and implications. Psychological Bulletin, 135, 69-93. doi:10.1037/a0014213

Nathaniel, M., \& David, C. (2006). Family relation. Journal of Family Therapy, 34, 65-78.

Nelson, M. O., \& Jones, E. M. (1957). An application of the Q-Technique to the study of religious concepts. Psychological Reports, 3, 293-297. doi:10.2466/pr0.1957.3.3.293

Nelson, P. B. (1990). Intrinsic/extrinsic religious orientation of the elderly: Relationship to depression and self-esteem. Journal of Gerontological Nursing, 16, 29-35.

Newton, A. T., \& McIntosh, D. N. (2010). Specific religious beliefs in a cognitive appraisal model of stress and coping. International Journal for the Psychology of Religion, 20, 39-58. doi:10.1080/10508610903418129

Nielsen, S. L., Johnson, W. B., \& Ellis, A. (2001). Counseling and psychotherapy with religious persons: A rational emotive behavior therapy. Mahway, NJ: Elbaum.

Orathinkal, J., \& Vansteewegen, A. (2006). Religiosity and marital satisfaction. Contemporary Family Therapy, 28, 497-504. doi:10.1007/s10591-006-9020-0

Rodriguez, C. M., \& Henderson, R. C. (2010). Who spares the road? Religious orientation, social conformity, and child abuse potential. Child Abuse \& Neglect, 34, 84-94. doi:10.1016/j.chiabu.2009.07.002

Ryff, C. D., Singer, B. H., \& Love, G. D., (2004). Positive health: Connecting well-being with biology. Philosophical Transactions of the Royal Society of London B. Biological Sciences, 359, 1383-1394. doi: $10.1098 /$ rstb.2004.1521

Ryff, C. D., \& Keyes C. L. M. (1995). The structure of psychological well-being revisited. Journal of Personality and Social Psychology, 69, 719-727. doi:10.1037/0022-3514.69.4.719

Sorajjakol, S., Aja, V., Chilson, B., Ramirez-Johnson, J., \& Earll, A. (2008). Disconnection, depression and spirituality: A study of the role of spirituality and meaning in the lives of individuals with sever depression. Pastoral psychology, 56, 521-532. doi: 10.1007/s11089-008-0125-2

Spanier, G., \& Cole, C. (1976). Toward clarification and investigation of marital adjustment. International Journal of Sociology of the Family, 6, 121-146. 


\section{T. YEGANEH, H. SHAIKHMAHMOODI}

Spanier, G. B. (1976). Measuring dyadic adjustment: New scales for assessing the quality of marriage and similar dyads. Journal of Marriage and the Family, 38, 15-28. doi:10.2307/350547

Stutzer, A., \& Frey B. S., (2006). "Does marriage make people happy or do happy people get married? Journal of Socio-Economics, 35, 326-347. doi:10.1016/j.socec.2005.11.043

Vanderbleek, L., Robinson, E. H., Casado-Kehoe M, \& Young, M. E. (2011). The relationship between play and couple satisfaction and stability. The Family Journal, 19, 132-139. doi:10.1177/1066480711399729

Williams, A. (2010). Spiritual therapeutic landscapes and healing: A case study of St. Anne de Beaupre, Quebec, Canada. Social Science \& Medicine, 70, 1633-1640. doi:10.1016/j.socscimed.2010.01.012

Wilson, Ch. M., \& Oswald., A. J. (2005). How does marriage affect physical and psychological health? A survey of the longitudinal evidence. www.findarticle.com

Yalcin, B. M., \& Karahan, T. F. (2007). Effects of a couple communication program on marital adjustment. Journal of the American board of family medicine, 20, 36-44. doi:10.3122/jabfm.2007.01.060053

Yang, K. P., \& Mao, X. Y. (2007). A study of nurses' spiritual intelligence: A cross-sectional questionnaire survey. International Journal of Nursing Studies, 44, 999-1010. doi:10.1016/j.ijnurstu.2006.03.004 Yarmohammadyan, A., Bonakdarehashemi, N., \& Asgari, K. (2011). The effect of emotional intelligence and life skills training on marital adjustment among young couples. Knowledge \& Research in Applied Psychology, 12, 3-12. 